\title{
Erratum to: Deformation-Induced Decomposition of Enstatite in Mantle Peridotite and Its Role in Partial Melting and Chromite Ore Formation
}

D. E. Saveliev ${ }^{a, *}$, Corresponding Member of the RAS V. N. Puchkov ${ }^{a}$, S. N. Sergeev ${ }^{b}$ and I. I. Musabirov ${ }^{b}$

Received January 30, 2019

DOI: $10.1134 / \mathrm{S} 1028334 \mathrm{X} 19010276$

The surname of the last co-author should read Musabirov

The original article can be found online at

https://doi.org/10.1134/S1028334X17090161.

\footnotetext{
${ }^{a}$ Institute of Geology, Ufa Science Center, Russian Academy of Sciences, Ufa, 450077 Russia

${ }^{b}$ Institute of Problems of Metal Superplasticity, Ufa Science Center, Russian Academy of Sciences, Ufa, 450001 Russia

*e-mail:savl71@mail.ru
} 